\title{
ONLINE GROUP PSYCHODRAMATIC PSYCHOTHERAPY: WARMING-UP REINVENTIONS
}

\author{
Aline Belém ${ }^{1, *}$ (iD
}

\begin{abstract}
This paper aims to discuss online group psychodramatic psychotherapy practices with an emphasis on warm-up. The hypothesis is that the warm-up step, specifically designed for Online care, contributes to the achievement of a more spontaneous group state. The theoretical north of the work is the warm-up stages proposed by Davoli (1999) from the experience with Spontaneous Theater. Thus, each stage is discussed taking into account the report of some experiences in conducting an online psychotherapy group. From these experiences, we affirm that the warm-up designed for this specific context provides good results in terms of group spontaneity.
\end{abstract}

KEYWORDS: Group psychodramatic psychotherapy; Warming-up; Online psychotherapy.

\section{PSICOTERAPIA PSICODRAMÁTICA DE GRUPO ON-LINE: REINVENÇÕES DO AQUECIMENTO}

\section{RESUMO}

Este trabalho tem por objetivo discutir práticas de psicoterapia psicodramática de grupo on-line com ênfase no Aquecimento. A hipótese é que o Aquecimento elaborado especificamente para o atendimento on-line contribui para o alcance de um estado grupal mais espontâneo. O norte teórico deste trabalho consiste nas etapas de Aquecimento propostas por Davoli (1999) através da experiência com Teatro Espontâneo. Assim, discute-se cada etapa a partir do relato de algumas experiências na condução de um grupo de psicoterapia on-line. A partir dessas experiências, conclui-se, então, que o Aquecimento concebido para esse contexto específico proporciona resultados satisfatórios em termos de espontaneidade grupal.

PALAVRAS-CHAVE: Psicoterapia psicodramática de grupo; Aquecimento; Psicoterapia on-line.

\section{PSICOTERAPIA PSICODRAMATICA DE GRUPO ON-LINE: REINVENCIONES DEL CALENTAMIENTO}

\begin{abstract}
RESUMEN
Este artículo tiene como objetivo discutir las prácticas de psicoterapia psicodramatica grupal on-line con énfasis en el calentamiento. La hipótesis es que el calentamiento diseñado específicamente para la atención en línea contribuye al logro de un estado grupal más espontáneo. El norte teórico de la obra son las etapas de calentamiento propuestas por Davoli (1999) a partir de la experiencia con el Teatro Spontâneo. Así, cada etapa se discute teniendo en cuenta el relato de algunas experiencias en la realización de un grupo de psicoterapia on-line. A partir de estas experiencias, afirmamos que el calentamiento diseñado para este contexto específico brinda buenos resultados en términos de espontaneidad grupal.
\end{abstract}

PALABLAS-CLAVE: Psicoterapia psicodramática grupal; Calentamiento; Psicoterapia on-line.

\footnotetext{
1.PROFINT - Profissionais Integrados - Aracaju (SE), Brazil.

*Correspondence author: alineobelem@hotmail.com

Section editor: Fernando Costa Cordovio

Received: 02 Dec 2020 | Accepted: 20 Mar 2021
} 


\section{INTRODUCTION}

The work with groups in psychodrama is quite diverse, and this diversity has expanded with each new combination of forces and ways of living in the world. As an example, we have spontaneous acts, public psychodrama, thematic and focal therapeutic groups, long-term procedural therapeutic groups (which will be more emphasized in this article), self-directed groups (relatively common in the training of didactic psychodramatists and supervisors) etc. Due to the current circumstances (Covid-19 pandemic and social isolation), we have experienced all these modalities of psychodramatic group work remotely on a large scale. There is a demand for online psychotherapeutic care for several other reasons, among them, the difficulty of mobility and the fact that many clients live in places with few or no therapists, culminating even in Resolution No. 011/2018 of the Federal Psychology Council, to regulate this practice (Vidal \& Castro, 2020). In this Resolution, the terms in which this work can occur, both in individual and group care, are defined, authorizing care and psychological consultations through communication technologies, synchronously and asynchronously. The resolution also requires the professional to specify which technological resources are used to guarantee confidentiality; inform your customers about this. It annually updates a specific register in the class council to provide this type of service.

At first, faced with what seemed to be the only alternative - suspension of therapeutic group meetings for an indefinite period - many psychodramatists launched themselves into the challenge of maintaining their psychodramatic therapeutic groups remotely; others have even created new groups, bringing together participants from different parts of the country and residents of other countries - all in the quest to provide everything that is valued in working with groups in general and, in particular, what is valued in psychodrama. After all, if we were attending in a bipersonal way (or psychodrama for two, only therapist and client participate) remotely, we should not fail to attend to groups. Davoli $(1999$, p. 80) asked: "If the locus of health/disease occurs in groups, why have we stopped attending groups?". This question brought up a few years ago continues to deserve our attention as psychodramatists, especially at a time of humanity considered critical, chaotic and iatrogenic for the most diverse reasons (pandemic, political polarization, environmental disasters, in short, the list would be huge).

Thus, from the basic guarantees for online psychodramatic group psychotherapy, the main challenges emerge: a) ensuring group secrecy without control of the environment where the session takes place for each participant; b) warming-up the group and keep the warming furnace on without physical contact; c) access the body's signals in the therapeutic process through a screen (a challenge for the whole group, not just for the therapist), mapping their clues and giving them a voice; d) legitimize interactions, even when interruptions occur due to a drop in connection; e) to manage the fatigue of the screen and the consequent cooling down caused by it; f) conducting scenic work without the need for physical space and all the resources it offers, through the creation of interaction strategies between participants and between the protagonist and auxiliary ego.

Given the above, this article aims to discuss the practice and challenges of online group psychodramatic psychotherapy, addressing theoretical-conceptual reflections, technical strategies, experiments and possibilities (sometimes, impossibilities), with particular attention to the warm-up phase. At the time of writing this, the author conducted two groups of psychodramatic psychotherapy online, and in this work, some experiences from only one of them will be presented. It is worth mentioning that the experiences discussed here are not intended as models to be followed, as conserved formulas on how to act, but as sources of inspiration for new reinventions, in the context of each group. Also, we will assume that investment in the warm-up specifically contextualized for remote care is of great importance to provide a state of greater group spontaneity.

It is necessary to show that we do not defend the equivalence or the mere transposition of the psychodrama carried out in person to the online context. These practices require unique care and have different potentials and limitations, although anchored in the basic principles of professional ethics and the philosophical and conceptual bases of socionomy. By reducing online performance to a transposition of face-to-face work, we neglect a series of challenges, such as those mentioned above, in addition to critical aspects, such as the ways of human relationships in times of significantly reduced physical contact. 
We will treat online group psychodramatic psychotherapy as a form of action, without subjugating it (when we focus only on the losses resulting from the absence of physical contact) or romanticizing it (when we focus only on its advantages, such as bringing together people from different places). This work is also supported by the fact that online group psychodramatic psychotherapy has been the alternative found by several groups. In some cases, it appears to be a strategy that will be established, especially for groups that enable meetings between people from cities, different countries and cultures.

There were countless experiences of a congregation in online focal psychodramas, in psychodramatic experiences, courses and also in the last Brazilian Congress of Psychodrama (entirely online), in which the importance of being able to bring together people from different regions of Brazil was mentioned more affordable (that is, more people were able to get to know the work of great professionals without the burden of a trip to another state). Considering this reality, this article also aims to contribute to developing the theoretical and practical proposal of sociatry in the current times.

\section{METHODOLOGY}

This work consists of an experience report discussed based on categories proposed by Davoli (1999). Thus, to discuss the practice, challenges and possibilities of online group psychodramatic psychotherapy, we resort to the warm-up substeps proposed by the aforementioned author in her work on warming-up for spontaneous Theater, adopting this reference as an inspiration for re-creating warming-up strategies for children groups in remote work.

We will also expose the report of some interventions carried out with a procedural therapeutic group that has been meeting since 2016, with some rotation among its members, but that has maintained the same conformation since the moment we started to hold our online sessions, until the moment of making this work. The online sessions take place through the Zoom platform, and the participants accessed the room through a link and password sent by the WhatsApp application.

The group consisted of four women between the ages of 25 and 35 and met weekly for two hours each session. All participants signed the Free and Informed Consent Form, with their identities duly preserved in the reports. It is worth mentioning that this term was presented to the participants as soon as they joined the group. The sessions were recorded manually in a field diary

\section{Warming-up is the connection that does not "break"}

It is possible to affirm that the preparation made to adjust the theoretical, technical and technological support around a session also composes the warm-up. Espírito Santo (2017) states that the previous warm-up process can be called the director's pre-warm-up when discussing the director's warm-up. It can happen with the auxiliary ego, the protagonist and the audience. Thus, the "Pre-warm-up is the part of the preparation process that takes place inside a person and without the intervention of the director" (Bustos, 2005 as quoted in Espírito Santo, 2017, p. 10). Given this statement, we will start by addressing simple, but no less important, aspects of rehiring the psychotherapeutic process in online care.

When entering a bipersonal or group procedural therapeutic process, a contract must be executed, and in this contract, some specificities must be included, in the case of remote work. We consider it particularly relevant to include confidentiality in the contract and initial agreements. In the case of online group care, each participant must be committed to conducting the session in a place where he/she is alone (which also applies to the bipersonal modality), preferably with the use of headphones, as in an invasion situation of privacy (about which there are relatively common reports), the speech content brought by the other members of the group is preserved. Another issue pertinent to rehiring is, still, that each participant is responsible for their connection. We also recommend that the session be charged usually if someone loses their internet connection at the time of the session or there is much fluctuation in the network. These guidelines, when offered objectively, contribute to the group being organized and co-responsible for the moment of the session.

The warm-up of a psychodramatic session is a step and a condition for spontaneous acts in general. Considered by Davoli (1999) as the creation matrix itself, the author presented the warm-up in five substeps, separated for didactic effects, from her experience with spontaneous Theater. We will use this reference, but it is important to emphasize that the focus 
here is not the training of spontaneous Theater actors but the inspiration to foster spontaneity in remote service in one of Psychodrama's primary sources, Spontaneous Theater. Therefore, we will borrow the author's subdivision for our presentation of strategies in remote work. The substeps described by Davoli (1999) are: a) setting; b) grouping; c) preparation for the role of an actor; d) preparation for the role of the author; e) audience preparation.

For the author, in the setting, one should use the resources that the environment offers, considering the physical space and familiarizing the participants with it, keeping in mind that "the environment must be very well known and recognized" (Davoli, 1999, p 81). Thinking about working online, the setting will be carried out in physical environments that differ from one member to the other and often happens in an entirely virtual environment (WhatsApp group, for example, in which people combine dates, times, inform unforeseen events and sometimes events in their lives to be objects of work in the session).

Following the idea of using what the environment offers, we present a strategy experienced in the therapeutic group to bring as an example in this work. In one of the sessions, we proposed that each person present their environment to the group, walking through it with their notebook, tablet or cell phone. The objective was to build connections, strengthen ties between participants and reinforce security and confidence in secrecy. The participants were used to face-to-face meetings until the pandemic by Covid-19 broke out. Thus, the following slogan was given:

Show where you do the session, show the corners and objects that you inhabit and/or use the most, show if you have doors or windows and, if possible, don't be shy by the possible mess. Let us make a pact: I will show you my mess and you will show yours.

At the same time that the environment was explored, each person was encouraged to feel entering the world of the other, experiencing every corner, bed, door, pillow, etc., allowing themselves to be affected and attracted by the elements present in the environment of the other. For example: one of the people in this group does the session from inside his car in the condominium garage. She then showed her car, her son's car seat, toys, briefcases, etc. Moreover, at other times, when a person was doing a session in a new environment, they were invited to present the new environment to the group as well. Here is a brief account of the warming-up of the session cited as an example:

\section{Report 1: On-line setting (the warm-up by the environment)}

All participants were present at the session. One of them was at her parents' house, in a country town, and started showing how the environment was different that day. The colleagues asked some questions, jokingly, in a very relaxed atmosphere. I suggested that everyone hold their device (tablet, cell phone, notebook) and, one at a time, show their environment, present objects or corners that they considered important. In contrast, the others would be attentive to every detail presented, feeling like someone that enters the life and environment of the other, observing their sensations on that trip.

Then, we proposed that the participants observe if something in any visited environments caused affectation, curiosity or any differentiated emotion. Thus, each person spoke which element caught their attention in an environment that was not their own, which were: a window facing the street, the bathroom of a suite, a guitar and a folder of documents inside a participant's car. Each person was warmed up and interviewed on the role of the chosen object. Participant Valéria (fictitious name) was with a baby, her first child, facing difficulties before motherhood to gain financial and emotional independence, considering herself incapable and insecure. This person chose another participant's car document folder as the element that most affected them. Here is an excerpt from Valéria's interview on the document folder:

Therapist: Hello, documents folder, tell me a little bit about yourself. How are you?

Documents folder: I am organized, forewarned and responsible ... 
Therapist: You know, Valéria, she has some difficulties in life in relation to financial independence, self-confidence ... What would you say to her?

Documents folder: Valéria, I am what you need right now: organization. After all, from now on, you'll never be alone again ...

In this same session, another participant was interviewed in the role of the suite bathroom in the home of one of the participants, who was single and had a room with an exclusive bathroom for herself. The participant who chose this bathroom is the mother of two small children and takes care of the elderly father. Here is an excerpt from Carolina's interview on the role of the suite bathroom:

Therapist: Suite bathroom, what is your most striking feature?

Suite Bathroom: I am freedom. I offer privacy and generate nostalgia in Carolina ... She doesn't know what privacy is anymore, she needs to create a suite bathroom like me in her life.

Another relevant point, not only about the setting in the warm-up stage but about the use of physical initiators in general, is that, in addition to being able to "enter" into the physical environment of the other through the image, you can also use intermediate objects easy to find (clothes, hygiene utensils and objects from everyday life, from the "trivial" world), so that everyone can share the experience with the available resources. It is worth emphasizing that the use of intermediate objects is pervasive in Psychodrama. Perazzo (2018) states that the intermediate object in psychodrama refers to the use of the technique of Moreno's empty chair, unfolding in the use of several other objects (pillows, fabrics, photographs, masks, etc.). Guimarães (2020) discusses the use of intermediate objects in online service, including classifying them (in auxiliary objects, mediating objects and creative objects).

The imaginative function will always be activated in any experiments, even if the same intermediate objects are not used. In this sense, Naffah (1979) discusses the notion of "mental initiator" as unfeasible, for the simple fact that "mental images are always made possible by a condition that is before them and fundamental and, for that same reason, is the only one that can 'start' something "(p. 67). Thus, the imaginative function will always capture every experience, whether with physical initiators or not. An example of this was when psychodramatist Michele Carvalo Nogueira (2020), in the warm-up of her experience of mourning at Profint's first Online Psychodrama Journey, Aracaju (SE), in July 2020, proposed that everyone come in and watch as if they felt inside a hut. For this, she asked everyone to look for a sheet, blanket, fabric or coat and "get in" it as if it were a hut. Even though using different objects from each other, found in the environments of each person, the group, in general, reached a good level of warm-up in the proposal of the experience.

Another interesting aspect, from the point of view of the setting, is that in the context of online service, there is a widespread virtual space nowadays, which are WhatsApp groups, social networks, etc. Inevitably, the contacts that take place in these virtual groups (which are no less accurate, as they produce practices and speeches) will be at stake in the warm-up process. In a session reported below, the participants started exchanging messages through the WhatsApp group that we created for purely operational purposes (schedules, schedule, absences, etc.). The topic under discussion between them was mobilizing the group, which arrived available to him in the session. At this moment, we had been in quarantine for almost three months, and feelings such as longing and need were very present. Thus, we opted to relax the rule of "strictly operational purpose" of the WhatsApp group, starting to handle these messages with the warm-up look, sometimes even reading some of them in session. It is important to note that WhatsApp does not intervene. The content is only addressed at the time of the session. However, we risk not having a very restrictive attitude concerning what the participants talked to in this virtual environment. Here is a brief account:

\section{Report 2: Where is my São João?}

This session took place on an important holiday for most cities in the Northeast of Brazil, when São João (St. John's) Day is celebrated. The June festivities bring together people of all ages, from different groups and social classes. Many people 
light fires in front of their houses, gather friends, make typical foods and dance to the accordion. It is a genuinely constitutive celebration of Northeastern culture and, in the year 2020, for the first time, we lived a night in São João without a celebration.

Having made this preamble, what happened before this session was that, in the WhatsApp group, the participants asked if there would be a session even if it were on the night of São João. The State Government had anticipated this holiday to keep the trade closed for another day, at the beginning of the pandemic, when we had no idea how long it would last. Then, we confirmed that there would be a session unless the group chose to deselect it. The group consented to do the session and began to regret, by messages, the lack that São João was on the street, especially the strangeness they felt about spending a night of São João inside their homes. One of the participants stated: "I prefer to do a session so as not to be sad thinking about it, I prefer not to think?". The messages about this continued, and we realized that these affections were effervescent at that moment, so we proposed that the participants send a typical São João song that they liked very much to represent that moment for us to discuss in session.

The session started with an unusual silence in that group as if what had to be said had already been said by the messages exchanged by the cell phone. So I shared my screen with YouTube, exposing the video for each song chosen. They all listened to the songs with involvement, emotion and singing together when they knew how to sing. I suggested that they bring just a single word about what they were feeling at that moment, and the words were: connection, happiness, longing and anguish.

At that time, the grouping process (we will discuss it later) already happened by simply listening carefully to the music chosen by the other person. The people who chose "happiness" and "connection" formed a subgroup, and the other subgroup was formed with the two people who brought "nostalgia" and "anguish" as feelings. They had a few minutes between each other to create a short scene, with a beginning, middle and end. Before starting the scenes, we suggest that the characters describe the environment they were in, the people in it (if there were any), whether day or night, as a symbolic setting for a specific warm-up.

The two scenes created brought, coincidentally, a dialogue between two people with projections for the future: the first (group of "anguish" and "longing") brought the participants two years later, talking through the window of the house as neighbors (referring to one of the songs, "Esperando na Janela", by Gilberto Gil) and commenting that the vaccine against Covid-19 was about to arrive. This scene provided access to fears and insecurities concerning the pandemic and how much more nonconformist and difficulty adapting to the situation. A participant was, through the speeches of his character. In sharing, she stated that she did not expect her colleague, in the role of homesickness, to say that the vaccine would only come in two years, and this made her desperate, with statements such as "I do not see myself wearing a mask for two years" and "I do not know if I can take it".

The second scene (inspired by the feelings of "happiness" and "connection") took place five years later, at a June party around a campfire, with no more pandemics. In the scene, there was a dialogue between a character who was the participant already divorced (at the time of the session, she was married) and the second character, who was the other participant married and with children (at that time, she had no children and was thinking about separate from the partner). The scene brought access to several expectations and the way the participants felt in that place designed for the future, with an inversion of roles between the married and divorced participant, experiencing the nuances of these roles in the scene, connecting them with their current conflicts and your wishes not stated until then. One of them, who was very inclined to separate from her partner, said during a soliloquy that she felt thrilled in that role: married to the same partner and children. This participant also affirmed, in the sharing, that "deep down" she knew that this was what she wanted but still lacked something that she did not know how to name.

As the participants appropriated those characters, they became more interested in the outcome of the scenes, with suggestions and experimentation of new outcomes on the part of the group as a whole.

In sharing, the speeches were unanimous around the importance of having resorted to the messages exchanged by WhatsApp with the resonances that the suspension of the June festivities caused in the group, with emphasis on a speech that stated that it was "very important to start the session without speaking. Starting the session by speaking had brought me more anguish at times, I also did not want to think".

One of the several objectives of the warm-up is to favor telic contact. Tele is discussed by Nery (2010) as "reciprocity in some dimensions of human existence or deep mutual sensitivity" (p. 35). This mutual sensitivity was built to the extent that the group felt heard from the beginning (WhatsApp messages) and were willing to listen and get involved with the sensations experienced by the other participants through the songs. 
One of the several objectives of the warm-up is to favor telic contact. Tele is discussed by Nery (2010) as "reciprocity in some dimensions of human existence or deep mutual sensitivity" (p. 35). This mutual sensitivity was built to the extent that the group felt heard from the beginning (WhatsApp messages) and were willing to listen and get involved with the sensations experienced by the other participants through the songs.

Following the substeps of the warm-up proposed by Davoli (1999), the grouping would prepare people to become a group. According to the author, the grouping involves the insertion of the group in a typical dramatic project - which goes beyond the simple "knowing oneself" by name, age or profession -, configuring collective delivery to the group psychotherapeutic process. Spontaneous Theater offers many possibilities for group production, with extensive use of exercises in the physical space. The focus of the grouping process is, in short, "to work the groups in groups" (Davoli, 1999, p. 82). So, how can we do this in a remote context?

We realized that when we started to attend the therapeutic group remotely, there was a concern about the "run over" lines and the open microphones at the same time. We also noticed that this personal concern slipped in the group because although they already knew each other and had lived several moments together, the participants were excessively obeying the speaking time, the sequence, "each one's turn". We felt a specific cooling down and loss of spontaneity in the first online meetings with the group. It was necessary to recreate a new group rhythm so that we could return to collective actions, with exercises for the participants to overcome the challenge of paying attention to themselves and to the other participants, simultaneously and through the screen.

Davoli (1999) warns about the importance, in a culture marked by narcissism and individualism, of learning to complement another person's action, which opens space for spontaneity in-group relationships. In the search for this rescue of the group to act remotely, some strategies used were based on dramatic games already known (example: "the significant other presents me", adapted in the group to "the significant other tells how I am today"). Another strategy used in the online group has been to allow some participants to interview to warm-up another participant in the character. For example, the protagonist is in the role of her sister and, instead of the therapist starting the interview on the role, encourage some other participant to do it first, with questions such as "what would you ask the sister so that we can get to know her better?".

As in group psychodramatic psychotherapy, the participants are also, in many moments, auxiliary egos. There must also be some care for the preparation in the role of auxiliary ego, for which we will bring the preparation in the role of actor presented by Davoli (1999). In the context of online psychodramatic psychotherapy, the most systematic strategy has been the role interview. Both the protagonist and the auxiliary ego are warmed up in the role of some character. However, it is necessary to be careful with the excess of interviews, which can have the opposite effect (cooling down). Thus, the management must assist the group participants with slogans such as:

Rescue (or create, in the case of imaginary characters) the tone of voice of this person/creature/feeling, the way in which he moves while speaking, his gestures and more striking expressions... It will bring this to your body and your face, to your voice.

One of the challenges for running an online therapeutic group is the absence of the interacting body, making it more challenging to create a welcoming environment (Weinberg, 2020). In this sense, it is recommended that preceding an interview on paper, there is a body warm-up, either for relaxation or greater energization. Davoli (1999) proposes that the warming-up of the Spontaneous Theater should prepare the body and voice, so, after these exercises, we can suggest, whenever someone takes on the role of a complementary person, that they listen to the other person's report "with the whole body". Listening with the whole body, said Naffah (2014), is listening dionysically, as you hear music, allowing yourself to be affected by the speech of the other.

When warming-up on the role, we can propose that the person brings themselves the gestures and the tone of voice of that character. Moreover, although the subject does not personally know the character they will play, we suggest that they build this character for itself as they imagine it to be, emphasizing that the protagonist may suggest changes throughout the scene (for example, when the protagonist chooses a person to play a complementary role in their life). 
Still, on this reconfiguration of the relationship with the body in online group care, Weinberg (2020) warns that we are more sensitive to facial expressions since they are close-up. We add that this is true for the whole group, not just for the therapist. We noticed that the group members also refined the ability to perceive emotional changes through the facial expression of their colleagues and the therapist. We often hear comments like "what was the face you did when I mentioned this?" or "your face is not good today. I noticed that when you opened the camera".

It is also important to create conditions so that the contents brought in the group are viable for dramatization, which Davoli (1999) calls preparation for the role of the author. This care in the online context does not differ so much in relation to the face-to-face context. We need to pay attention to creating characters, the presentation of a context and scenic elements to work in any situation. Besides, it is essential to maintain the involvement of everyone in the group in the scene, either by inviting or proposing to enter the scene in place of an existing character or by bringing in new characters. For this to happen, people who are not in scenic interaction can, for example, keep the camera closed so that only those on the scene appear, simulating a virtual "stage", opening their cameras at the time they are requested or when the scene ends. I participated in some experiences and workshops where directors used this strategy very well, but in large groups. In the case of a small group, such as the one we brought as an example, there are sessions where people are tired of a long day at work or caring for young children. Eye contact is necessary to keep them as a family audience, available and warm to take on a character, a musical background, new outcomes, etc.

This fatigue has often mobilized everyone in the group: the participants and me. The longing for São João, the tiredness with the domestic routine, work and children at home without being able to go to school all crossed us as well. We refer to the pandemic: it is perhaps the first time that clients and therapists have experienced the same drama simultaneously, at least on this scale and intensity. The last report addresses exactly the limits imposed by this circumstance:

\section{Report 3: Coping with limits and difficulties}

We will deal here with the limitations of the warm-up when the director and the group are in a state of great tiredness because of the excess of online activities, with long periods of exposure to the screens, in addition to the longing for face-to-face meetings, since this it was previously a group of face-to-face sessions. Two of the four participants had already reported much tiredness with the use of the screen, as they had also been working remotely for some months, claiming to arrive at the session with sleep and with a tired mind. This was also the director's feeling. This was followed by some exclusively verbal sessions, which left the director with a sense of frustration as a psychodramatist, feeling cool and longing for face-to-face contact. It is thought about the possibility of changing schedules (from night to day), which would make the meeting unfeasible for almost everyone, due to working hours and child care. What to do?

One of the great joys of accompanying a group for a few years is seeing that the group matures, improves its forms of communication and, in some special situations, warms us more than we do it. In this cooling period, one of the participants said that she felt tired and that she would like the director to resume a more directive stance, as when we started the group years ago. Besides, she spoke empathetically that she also recognized and understood the director's tiredness and proposed that we look for other forms of interaction in that difficult moment - very pertinent speech, because despite being a mature and open group, that moment asked for a kind of restart, from (re) training of group client roles, now online. Thus, we started to rescue strategies and reconnection games that provided a new spirit for the group and a rewarming for the director, based on the premise that the group must be trusted. This is a learning experience that reinforces that the director or director of groups must seek a global position in relation to the other, incorporating the role of therapist-interventor-observer-participant (Nery, 2010).

\section{FINAL CONSIDERATIONS}

Given the experiences discussed in this article, we observed that it is essential to emphasize that creativity and spontaneity must be rescued, stimulated and cared for, even when it comes to the role of group director. There are several proposals for 
warming-up groups in the different group approaches. In all of them, we understand that the group's movement is generous and gives the tone of the warming that needs to happen at that moment.

At this point, it is up to us, psychodramatists, the responsibility of never forgetting that the "cake recipes" exist but that the most fruitful paths will always be those presented in the here-and-now.

The warm-up in the psychodramatic process will always be volatile, asking for constant attention to the context. When we work with online groups, we have a context design that, by itself, promotes changes in the subjective conformation of the group, which is no longer seen in the full-body (unless an exercise is proposed for this), which, at the same time, you see yourself in close-up at all times. You have to be more warmly encouraged to interact and get to know yourself intimately since the welcoming body expression will be framed on the screen.

The proposals for setting, grouping, preparing to be an auxiliary ego and to be an author (Davoli, 1999) are offered as good clues for the expansion of performance in the context of remote service, as already exposed above. We claim to be clues, not a model, and we conclude that investing in the warm-up specifically for the conditions of online service provides good results in terms of group spontaneity.

The proposal described by Davoli (1999) was the inspiration for action that unfolded in this work. However, other sources of inspiration in Psychodrama have contributed to new psychotherapy practices remotely. We note that they agree, in principle, that the face-to-face process should not be transposed to the online service. Fleury (2020), for example, states that "creativity will be more productive the more it is supported by the specifics of this new therapeutic setting"(p.3). Thus, it is up to us, psychodramatists, to create warming-up strategies that promote the same role as spontaneity-creativity in the psychodramatic process in a remote context.

\section{DATA STATEMENT AVAILABILITY}

All the data was generated in the current study.

\section{FUNDING}

Not applicable.

\section{ACKNOWLEDGMENTS}

Not applicable.

\section{REFERENCES}

Davoli, C. (1999). Aquecimento: Caminhos para a dramatização. In W. C. Almeida (Org.), Grupos: A proposta do Psicodrama (pp. 77-88). Ágora.

Fleury, H. J. (2020). Psicodrama e as especificidades da Psicoterapia On-line. Revista Brasileira de Psicodrama, São Paulo, 28(1), 1-4. https://doi.org/10.15329/2318-0498.20203

Guimarães, L. A. (2020). Imagodrama: Uso de bonecos e objetos-auxiliares em psicodrama individual e on-line. Revista Brasileira Psicodrama, São Paulo, 28(2), 106-117. https://doi.org/10.15329/2318-0498.20039

Naffah, A. N., Neto (1979). Psicodrama: Descolonizando o imaginário. Brasiliense.

Naffah, A. N., Neto (2014). A psicanálise e a herança de Nietzsche sob a forma de dez mandamentos. In S. M. Paulon (Org.), Nietzsche psicólogo: A clínica à luz da filosofia trágica (pp. 145-165). Sulina.

Nery, M. da P. (2010). Grupos e intervenção em conflitos. Ágora. 
Nogueira, M. C. (2020). Contribuições do Psicodrama para elaboração do luto. IJornada do Psicodrama On-line da Profint. Profint Profissionais Integrados.

Perazzo, S. (2018). O mito da cadeira vazia. Revista Brasileira de Psicodrama, São Paulo, 26(1), 101-107. https://doi. org/10.15329/2318-0498.20180020

Resolução CFP n. 11 (2018). Regulamenta a prestação de serviços psicológicos realizados por meios de tecnologias da informação e da comunicação e revoga a Resolução CFP n. 11/2012. Conselho Federal de Psicologia.

Vidal, G. P., \& Castro, A. (2020). O Psicodrama clínico on-line: Uma conexão possível. Revista Brasileira de Psicodrama, São Paulo, 28(1), 54-64. https://doi.org/10.15329/2318-0498.20196

Weinberg, H. (2020). Online Group Psychotherapy [Webinar]. American Association of Group Psychotherapy. 